University of Nebraska - Lincoln

DigitalCommons@University of Nebraska - Lincoln

Biological Systems Engineering: Papers and

Publications

Biological Systems Engineering

2010

\title{
Ultrasound-Assisted Osmotic Dehydration of Strawberries: Effect of Pretreatment Time and Ultrasonic Frequency
}

\author{
Juan Garcia-Noguera \\ University of Nebraska-Lincoln \\ Francisca I. P. Oliveira \\ Universidade Federal do Ceará, Brazil \\ Maria Izabel Gallão \\ Universidade Federal do Ceará, Brazil \\ Curtis L. Weller \\ University of Nebraska-Lincoln, cweller1@unl.edu \\ Sueli Rodrigues \\ Universidade Federal do Ceará, Brazil \\ See next page for additional authors
}

Follow this and additional works at: https://digitalcommons.unl.edu/biosysengfacpub

Part of the Biological Engineering Commons

Garcia-Noguera, Juan; Oliveira, Francisca I. P.; Gallão, Maria Izabel; Weller, Curtis L.; Rodrigues, Sueli; and Fernandes, Fabiano A. N., "Ultrasound-Assisted Osmotic Dehydration of Strawberries: Effect of Pretreatment Time and Ultrasonic Frequency" (2010). Biological Systems Engineering: Papers and Publications. 190.

https://digitalcommons.unl.edu/biosysengfacpub/190

This Article is brought to you for free and open access by the Biological Systems Engineering at DigitalCommons@University of Nebraska - Lincoln. It has been accepted for inclusion in Biological Systems Engineering: Papers and Publications by an authorized administrator of DigitalCommons@University of Nebraska Lincoln. 


\section{Authors}

Juan Garcia-Noguera, Francisca I. P. Oliveira, Maria Izabel Gallão, Curtis L. Weller, Sueli Rodrigues, and Fabiano A. N. Fernandes 


\title{
Ultrasound-Assisted Osmotic Dehydration of Strawberries: Effect of Pretreatment Time and Ultrasonic Frequency
}

\author{
Juan Garcia-Noguera, ${ }^{1}$ Francisca I. P. Oliveira, ${ }^{2}$ Maria Izabel Gallão, ${ }^{2}$ \\ Curtis L. Weller, ${ }^{1}$ Sueli Rodrigues, ${ }^{2}$ and Fabiano A. N. Fernandes ${ }^{2}$
}

1. Department of Biological Systems Engineering, University of Nebraska-Lincoln, Lincoln, Nebraska, USA

2. Universidade Federal do Ceará, Departamento de Engenharia Química, Campus do Pici, Fortaleza, Brazil

Corresponding author - Fabiano A. N. Fernandes, Universidade Federal do Ceará, Departamento de Engenharia Química, Campus do Pici, Bloco 709, 60455-760, Fortaleza CE, Brazil; email fabiano@ufc.br

\begin{abstract}
Pretreatment of fruits prior to drying has shown success in reducing drying time and costs. In this work, ultrasound-assisted osmotic dehydration has been implemented as a method to increase water diffusivity and reduce drying time in strawberries. Strawberry halves were immersed in distilled water and in two different concentrations of sucrose solutions while pretreatment time and ultrasonic frequency levels were varied to determine their effect on drying time, water loss, and soluble solids gain. A microscopic analysis was carried out to evaluate the formation of microchannels and other changes to the fruit tissue structure. Greater sucrose concentration used in ultrasound-assisted osmotic dehydration resulted in greater water loss with greatest loss observed for the strawberry halves pretreated for $45 \mathrm{~min}$ in a $50 \% \mathrm{w} / \mathrm{w}$ sucrose solution. The pretreatment carried out for 30 min employing an osmotic solution of $50 \% \mathrm{w} / \mathrm{w}$ of sucrose resulted in the highest drying rate among the pretreatments. Osmotic dehydration used alone during pretreatment increased total processing time, whereas osmotic dehydration combined with ultrasonic energy during pretreatment reduced total processing time and increased effective water diffusivity. Cell distortion and breakdown were observed not only in pretreatments employing ultrasound-assisted osmotic dehydration but in conventional osmotic dehydration. Formation of microchannels through ultrasonic application and effects of osmotic pressure differential were considered to be largely responsible for reducing drying time for strawberry halves.
\end{abstract}

Keywords: drying, osmotic dehydration, strawberry, ultrasound

\section{INTRODUCTION}

Increasing consumer demands have resulted in the extensive development and improvement of food preservation technologies. From an industrial perspective, drying represents the most widespread method for food conservation. Yet, from a thermodynamic point of view, drying constitutes one of the most complex transport phenomena, because it involves the occurrence of several simultaneous stages of mass and heat transfer.

Drying processes are based on an energy-intensive mechanism. Cost reductions can be attained by optimi- zation of air-drying periods. New pretreatments of materials to be dried, usually based on chemical manipulation, have successfully reduced drying times. ${ }^{[1-4]}$

Traditional processes such as osmotic dehydration have recently gained a renewed and increased interest, mainly as a pretreatment in combined techniques. ${ }^{[5-8]}$ Osmotic dehydration consists of immersing the material to be dried in a hypertonic solution. It is characterized by a net opposite flux of water and solutes that allows the tissue of the material to become concentrated with a determined ratio solute gain/water loss, depending on process conditions. ${ }^{[9]}$

New methodologies, such as ultrasound-assisted osmotic dehydration, have been implemented as an alternative pretreatment associated to drying procedures. Reduction of drying time and, consequently, processing costs have recently been reported at the experimental scale after research conducted on several fruits and vegetables. ${ }^{[6,10,11]}$ Ultrasound has been recently studied and applied as a pretreatment to air drying and freeze drying and has shown to increase the mass transfer rate during drying. ${ }^{[12,13]}$

The present study has analyzed the effects of ultrasound-assisted osmotic dehydration as a pretreatment in strawberry. Samples immersed in distilled water and in two different osmotic solutions were compared. Pretreatment time and ultrasonic frequency levels were varied to determine their effect on drying time, water loss, and soluble solids gain. A microscopic analysis was carried out to compare the formation of microchannels in strawberries with those formed in other fruits.

\section{MATERIALS AND METHODS}

\section{Preparation of Samples}

Strawberries, Camarosa cultivar (mostly conic and long conic shaped) were purchased from retail markets (Fortaleza, Brazil). Strawberries were cut in half along their long axes. Each half was weighed and halves within a range between 4 and $9 \mathrm{~g}$ were selected. 
Strawberries were classified based on a relative standard of maturity, shape, and color. Such classification stage was intended to select similar berries to be used in every experiment, as well as to discard ripe, damaged, or moldy samples. The initial moisture content of berries was determined by heating strawberry halves in a drying oven (Marconi model MA-085, Piracicaba, Brazil) at $60^{\circ} \mathrm{C}$ for $48 \mathrm{~h}$ following AOAC method 934.06. ${ }^{[14]}$ The initial concentration of soluble solids ( ${ }^{\circ}$ Brix) of the berries was calculated reading the refractive index on a refractometer (Atago model AT35, Tokyo, Japan).

\section{Pretreatment}

Pretreatments were structured in combinations of four time intervals: 10, 20, 30, and $45 \mathrm{~min}$; three solutions: distilled water and two osmotic concentrations; and three ultrasonic frequency levels: 0, 25, and $40 \mathrm{kHz}$. Pretreatments carried out at $0 \mathrm{kHz}$ were not subjected to ultrasound and were considered as control runs.

Each experimental unit was immersed in a separate 250-mL Erlenmeyer flask filled with $100 \mathrm{~mL}$ of pretreatment solution. The osmotic solutions were prepared mixing food-grade sucrose with distilled water until concentrations ( $\% \mathrm{w} / \mathrm{w}$ sucrose in water) of 25 and $50 \%$ were attained. The weight ratio between the fruit and the pretreatment solution was 1:4 to avoid dilution effects. ${ }^{[15]}$

The ultrasonic pretreatments were carried out using two ultrasonic baths (Unique models USC25 and USC40, Indaiatuba, Brazil; internal dimensions: $24 \times 14$ $\times 9 \mathrm{~cm}$; volume: $2.7 \mathrm{~L}$ ) without mechanical agitation. The operating frequency of one bath was $25 \mathrm{kHz}$ and the other bath operated at $40 \mathrm{kHz}$. Temperature of the liquid medium was maintained at $30^{\circ} \mathrm{C}$.

In each ultrasonic pretreatment trial, a total of four flasks (one for each time interval) was filled with one specific solution and placed in the corresponding ultrasonic bath. For control pretreatments, four flasks containing the same solution were prepared and placed on the countertop and were not subjected to ultrasound. Both ultrasonic and control pretreatments were carried out simultaneously. All experiments were carried out in duplicate.

After completion of each pretreatment trial, strawberry halves (both from ultrasonic and control units) were removed from flasks, strained, and blotted with absorbent paper to remove excess solution. Weights for each experimental unit after ultrasound-assisted osmotic dehydration pretreatment were recorded. From each experimental unit replicate, one random sample was selected and held for microscopy image analysis.

The osmotic potential (OP) of the sucrose solutions and fresh strawberries was determined using Equation (1). This equation was derived from the van't Hoff's general formula.

$$
\Pi=-R T \sum_{i=1}^{n} C_{i}
$$

where $C_{i}$ is the concentration of the components of the soluble solids in the osmotic solution (mol/L), $R$ is the ideal gas constant $(8.314 \mathrm{~J} / \mathrm{K} \mathrm{mol}), T$ is the temperature $(\mathrm{K})$, and $P$ is the osmotic potential (MPa).

The response variables of water loss (WL) and soluble solids gain (SG) were determined using the weight of strawberry halves before and after the pretreatment trials, as well as the moisture content (wet basis) of strawberries before and after pretreatment. WL and SG were calculated according to Equations (2) and (3), respectively.

$$
\begin{aligned}
& W L(\%)=\frac{\left(w_{i} \cdot X_{i}-w_{f} \cdot X_{f}\right)}{w_{i}} \cdot 100 \\
& S G(\%)=\frac{\left(w_{f} \cdot X_{s f}-w_{i} \cdot X_{s i}\right)}{w_{i}} \cdot 100
\end{aligned}
$$

where $w_{i}$ is the initial fruit mass (g) before pretreatment; $w_{f}$ is the final fruit mass $(\mathrm{g})$ after pretreatment; $X_{i}$ is the initial fruit moisture content on a wet basis ( $g$ water/g total fruit mass) before pretreatment; $X_{f}$ is the final fruit moisture content on a wet basis ( $g$ water/g total fruit mass) after pretreatment; $X_{s i}$ is the initial fruit dry solid matter content (g dry matter/g total fruit mass) before pretreatment; and $X_{s f}$ is the final fruit dry matter content ( $g$ dry matter/g total fruit mass) after pretreatment.

\section{Air Drying}

After each pretreatment, the strawberry halves were placed in Petri dishes (flat surface up) in a single-layer arrangement and dried in a forced circulation air-drying oven (Marconi model MA-085, Piracicaba, Brazil). Air temperature in the oven was set at 60 ${ }^{\circ} \mathrm{C}$. Cross-flow air moved from side to side of the dryer at $0.5 \mathrm{~m} / \mathrm{s}$, flowing parallel to the width of the dryer shelves. Air relative humidity (16\%) was determined by psychrometry.

The water effective diffusivity of strawberries during the air-drying process was determined using the data of experimental moisture content over time. A parameter estimation procedure based on the minimization of the error sum of squares was used to calculate the water effective diffusivity of strawberries during air drying. The calculation was based on an approximation of Fick's second law (Equation (4)) for the falling rate period. ${ }^{[16]}$ This equation assumes that the surface of the sample is dry or at an equilibrium moisture content, that the initial moisture distribution is uniform, that the effective water diffusivity in the sample is constant, and that the thickness of the sample is small relative to the other dimensions (length and width of the sample).

$$
\frac{d M}{d t}=-\frac{2 \pi}{\delta^{2}} \cdot D \cdot\left(M-M_{e q}\right)
$$


where $D$ is the effective water diffusivity $\left(\mathrm{m}^{2} / \mathrm{s}\right) ; M$ is the moisture content $\left(\mathrm{g} \mathrm{H}_{2} \mathrm{O} / \mathrm{g}\right.$ dry matter); $M_{e q}$ is the equilibrium moisture content; $t$ is the time (s); and $\delta$ is the average transversal thickness of the fruit (m).

\section{Light Microscopic Analysis}

At the end of each pretreatment, one random sample from each experimental unit was carefully cut into cubes of $5 \mathrm{~mm}$ per side. Then the cubes were fixed by means of a $4 \%$ solution of paraformaldehyde in $0.1 \mathrm{M}$ phosphate buffer ( $\mathrm{pH} 7.2$ ) and 1\% glutaraldehyde for 24 $\mathrm{h}$ at ambient temperature. After fixation, the cubes were dehydrated, passing through a series of graded ethanol immersions and embedded utilizing a historesin embedding kit. Dehydrated and embedded cubes were then sectioned into layers of $5 \mu \mathrm{m}$ thickness with a Leica RM 2065 microtome (Leica, Germany). The periodic acid-Schiff reagent cytochemical reaction was employed for polysaccharide detection. ${ }^{[17]}$ Photomicrographs of layers showing cellular structure were taken using an Olympus BX51 light microscope (Olympus, Tokyo, Japan) with a digital image capture system.

\section{Experimental Design and Statistical Analysis}

An experimental design was used to study the effects of pretreatment time, ultrasonic frequency, and osmotic solution concentration on response variables: water loss and soluble solids gain. The independent variables were frequency (Freq) with three levels: 0, 25, and $40 \mathrm{kHz}$; osmotic solution concentration (Sol) with three levels: 0 , 25 , and $50 \%(\mathrm{w} / \mathrm{w})$; and time (Time) with four levels: $10,20,30$, and $45 \mathrm{~min}$. Values in the one-way analysis of variance (ANOVA) table were calculated using the Proc Mixed Model procedure of SAS (SAS Software v. 9.0, SAS Institute Inc., Cary, NC, USA). Significant differences within pretreatments were determined at $p<$ 0.05 (95\% confidence level). Tukey's HSD test was employed for comparison of means where significant differences occurred within the pretreatment combinations in terms of WL and SG responses.

Additionally, analyses of perturbation to determine the sensitivities of the performance measures (WL and SG) with respect to experimental parameters (Time and Sol) were carried out using the software Statistica v. 7.0 (Statsoft, Tulsa, OK, USA).

\section{RESULTS AND DISCUSSION}

The mean moisture content of fresh strawberries was $0.914 \pm 0.005 \mathrm{~g}$ water $/ \mathrm{g}$ fruit. The initial soluble solids of fresh strawberry was $5.0 \pm 0.2^{\circ}$ Brix. The cell structure of unpretreated fresh strawberry is shown in Figure 1. The cells of fresh strawberry were evenly distributed and of consistent semicircular shape with few distortion of the cells. Pectin-laced walls were intact and the tissue presented several interlamelar spaces.

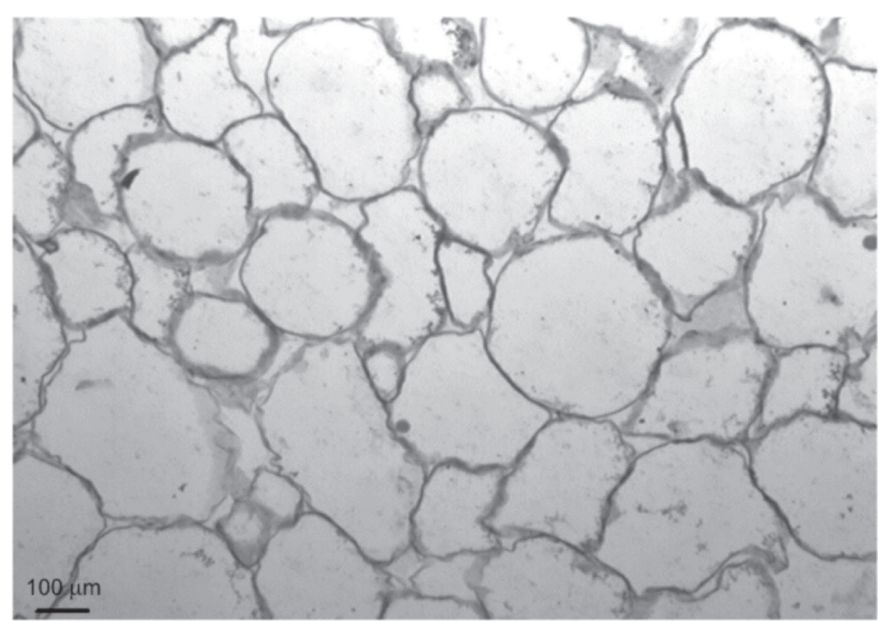

Figure 1. Cell cross sections from a thin layer of fresh strawberry tissue $(540 \times)$.

\section{Water Loss}

Water loss and sugar gain for strawberry subjected to ultrasound-assisted osmotic dehydration are presented in Table 1 . Strawberry pretreated in distilled water $(0 \%$ sucrose) gained moisture, whereas strawberries pretreated in either 25 or $50 \%$ sucrose solutions lost water to the osmotic solution.

The results showed an increase in water loss with increasing osmotic solution concentration, which is already expected because of the increase in the gradient between the soluble solids concentration in the fruit and in the osmotic solution. When the osmotic dehydration is not subjected to ultrasonic waves, a continuous increase in water loss is observed, except for the experiments where the fruit was immersed in distilled water. When ultrasound was applied to the fruit immersed in distilled water, a steep increase in water gain was observed between 30 and $45 \mathrm{~min}$, which may be related to the formation of microscopic channels and breakdown of tissue cells.

Figure 2 presents a photomicrograph of the stem and cortex sections of strawberry tissue pretreated by ultrasound for $20 \mathrm{~min}$ in distilled water at $25 \mathrm{kHz}$. Two regions are emphasized: Region A in which normal cells are present and Region B in which cell distortion and promotion of elongated cells are evident.

Figure 3 shows the stem and cortex sections of a strawberry pretreated by ultrasound in distilled water for $30 \mathrm{~min}$ at $25 \mathrm{kHz}$. Cell elongation is evident in Region A, which ultimately led to detachment of cells as observed in Region B. After 30 min of experiencing ultrasonic energy in distilled water, separation of cells in the strawberry tissue reached a stage in which microchannels could be observed (Region B) within the strawberry tissue. The formation of these microchannels promoted an increase in the drying rates observed for pretreated strawberry versus fresh strawberry. 
Table 1. Water loss and sugar gain during osmotic dehydration and ultrasound-assisted osmotic dehydration pretreatment of strawberry

\begin{tabular}{llll}
\hline $\begin{array}{l}\text { Osmotic solution } \\
\text { concentration }(\mathrm{w} / \mathrm{v})\end{array}$ & $\begin{array}{l}\text { Time } \\
(\mathrm{min})\end{array}$ & $\begin{array}{l}\text { Water } \\
\text { loss }(\%)\end{array}$ & $\begin{array}{l}\text { Sugar } \\
\text { gain }(\%)\end{array}$ \\
\hline
\end{tabular}

Osmotic dehydration without ultrasound application

$\begin{array}{rrrr}0 & 10 & -3.7 \pm 2.1 & -0.1 \pm 0.1 \\ 0 & 20 & -3.8 \pm 1.9 & -0.7 \pm 0.5 \\ 0 & 30 & -4.8 \pm 0.9 & -2.1 \pm 0.4 \\ 0 & 45 & -4.2 \pm 1.1 & -3.4 \pm 0.8 \\ 25 & 10 & 0.9 \pm 0.7 & 13.6 \pm 3.8 \\ 25 & 20 & 1.0 \pm 0.4 & 16.5 \pm 4.3 \\ 25 & 30 & 1.0 \pm 0.2 & 22.3 \pm 2.1 \\ 25 & 45 & 1.8 \pm 1.1 & 26.2 \pm 4.9 \\ 50 & 10 & 2.7 \pm 0.8 & 18.0 \pm 4.2 \\ 50 & 20 & 1.9 \pm 0.4 & 20.9 \pm 3.1 \\ 50 & 30 & 3.8 \pm 0.6 & 22.7 \pm 2.9 \\ 50 & 45 & 4.6 \pm 1.2 & 29.0 \pm 4.5\end{array}$

Ultrasound frequency: $25 \mathrm{kHz}$

$\begin{array}{rrrr}0 & 10 & -2.7 \pm 1.3 & -0.7 \pm 0.3 \\ 0 & 20 & -3.1 \pm 0.1 & -0.1 \pm 0.1 \\ 0 & 30 & -3.9 \pm 1.2 & -0.6 \pm 0.9 \\ 0 & 45 & -5.9 \pm 0.5 & -9.5 \pm 2.2 \\ 25 & 10 & 3.4 \pm 0.5 & 32.1 \pm 1.8 \\ 25 & 20 & 2.4 \pm 0.1 & 24.4 \pm 0.4 \\ 25 & 30 & 1.1 \pm 0.1 & 18.7 \pm 0.1 \\ 25 & 45 & 2.6 \pm 0.3 & 21.0 \pm 1.0 \\ 50 & 10 & 4.4 \pm 0.1 & 32.9 \pm 1.6 \\ 50 & 20 & 6.6 \pm 0.1 & 39.3 \pm 1.4 \\ 50 & 30 & 6.1 \pm 0.9 & 32.4 \pm 2.5 \\ 50 & 45 & 5.1 \pm 0.7 & 31.4 \pm 2.3\end{array}$

Ultrasound frequency: $40 \mathrm{kHz}$

\begin{tabular}{rrrr}
0 & 10 & $-3.0 \pm 0.3$ & $-0.8 \pm 0.6$ \\
0 & 20 & $-4.5 \pm 1.4$ & $-0.5 \pm 0.5$ \\
0 & 30 & $-5.1 \pm 0.9$ & $-0.4 \pm 0.5$ \\
0 & 45 & $-5.4 \pm 0.1$ & $-8.7 \pm 0.3$ \\
25 & 10 & $1.0 \pm 0.8$ & $23.0 \pm 1.9$ \\
25 & 20 & $0.4 \pm 0.4$ & $20.6 \pm 3.5$ \\
25 & 30 & $0.5 \pm 0.5$ & $23.6 \pm 1.1$ \\
25 & 45 & $1.3 \pm 0.2$ & $28.2 \pm 4.5$ \\
50 & 10 & $2.5 \pm 0.4$ & $26.8 \pm 3.6$ \\
50 & 20 & $2.3 \pm 0.5$ & $27.9 \pm 1.7$ \\
50 & 30 & $2.7 \pm 0.8$ & $29.8 \pm 2.0$ \\
50 & 45 & $4.6 \pm 0.2$ & $33.3 \pm 3.4$ \\
\hline
\end{tabular}

In distilled water, microchannel formation has been attributed exclusively to detachment and disruption of cells as a response to ultrasonic application. Ultrasound pretreatments in distilled water also did not induce breakdown of cells in previous experiments with melons, papayas, and pineapples. ${ }^{[18-20]}$ Cell distortion and

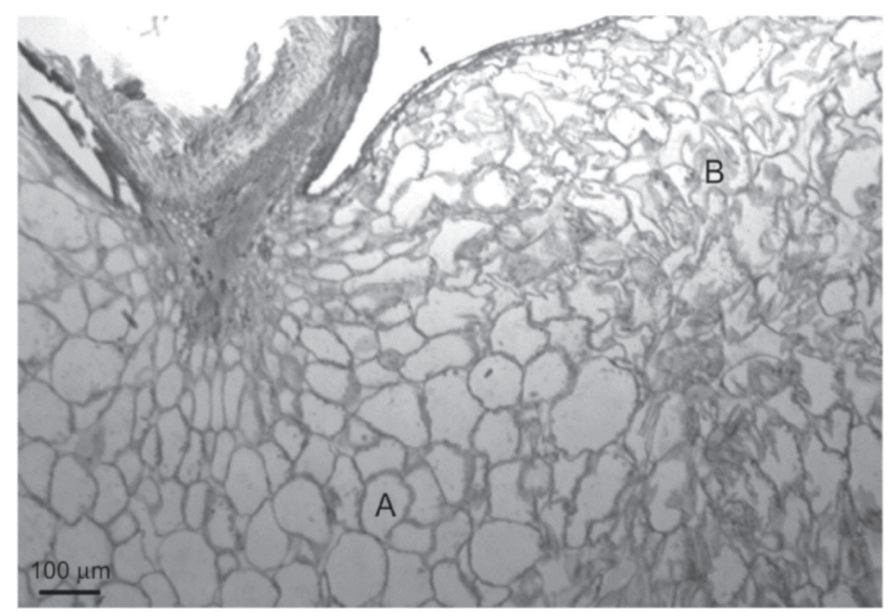

Figure 2. Photomicrographs of strawberry samples after $20 \mathrm{~min}$ of ultrasound exposure: (A) region with normal cells and (B) microchannel formation and elongated cells $(380 \times)$.

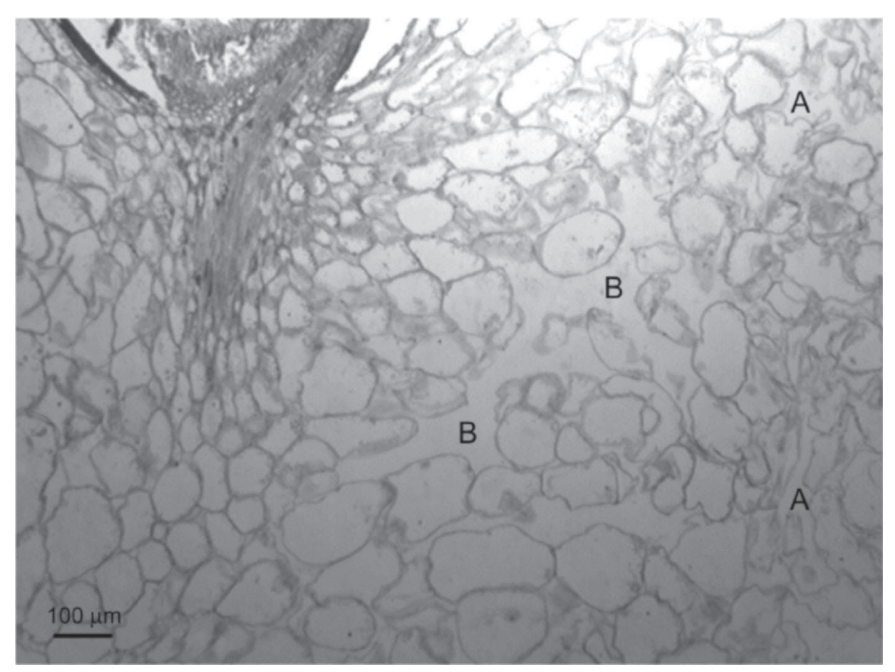

Figure 3. Photomicrographs of strawberry samples after $30 \mathrm{~min}$ of ultrasound-assisted osmotic dehydration: (A) microchannel formation and (B) microchannels region with disrupted cells (380×).

breakdown were observed in pretreatments employing osmotic dehydration without application of ultrasound. Prinzivalli et al. ${ }^{[21]}$ showed for strawberries undergoing osmotic dehydration that the texture of the fruit was modified due to pectin dissolution and breakdown of cells after $30 \mathrm{~min}$ of pretreatment periods.

In Figure 4 the epidermis section of a strawberry pretreated for $30 \mathrm{~min}$ at $25 \mathrm{kHz}$ in a $50 \% \mathrm{w} / \mathrm{w}$ osmotic solution is presented.

Three significant two-way interactions of Sol*Time, Sol*Freq, and Freq*Time were observed $(p<0.05)$ for the water loss data. Tables $2-4$ present the mean values for each of these interactions. 


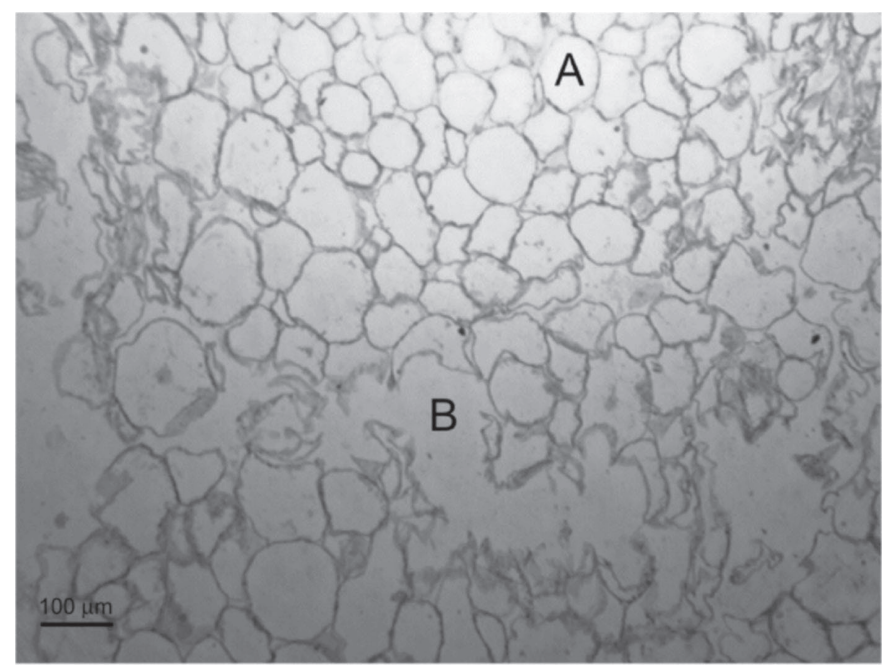

Figure 4. Photomicrographs of strawberry samples after $30 \mathrm{~min}$ of ultrasound-assisted osmotic dehydration: (A) region with normal cells and (B) microchannel region with disrupted cells (380x).

For the Sol*Freq interaction, the greatest amount of water was lost at the $50 \%$ osmotic solution concentration and $25 \mathrm{kHz}$ ultrasound frequency level and the least water loss was observed in distilled water at any frequency. Generally, the greater the sucrose concentration, the greater the water lost. Similar behavior has been reported by Fernandes et al. ${ }^{[18,22,23]}$ The lower water loss values for 25 and $50 \%$ osmotic solutions at 40 $\mathrm{kHz}$ than for the same solutions at $25 \mathrm{kHz}$ may have resulted from extensive damage to the strawberry tissue such that sucrose was able to enter into microchannels and coat the inter-tissue cellular surfaces. Also contributing to the lower values may have been the increased energy absorption by the solutions and the diminished penetration of ultrasonic waves into the strawberry tissue. ${ }^{[24]}$

Water loss values responded significantly different to the interaction of Sol and Time. For the strawberry immersed in distilled water, greater negative water loss (i.e., greater water gain) was observed over time. Such an observation was not unexpected because water from outside the strawberry halves diffused into the tissue to lower its osmotic potential $(-640 \mathrm{kPa})$, which was determined by the van't Hoffs equation based on the soluble fraction in fresh strawberries. However, the value of water gain by the fruit observed when distilled water was used (3-6\%) was higher than it would be expected by using the van't Hoff equation, where a water gain of approximately $0.2 \%$ would be expected. The difference observed can be attributed by the effect of ultrasound and the effect of the formation of microscopic channels in the sample.
Table 2. Water loss (\%) means \pm standard deviation for twoway (Sol*Freq) interaction during ultrasound-assisted osmotic dehydration pretreatment of strawberry

\begin{tabular}{cccc}
\hline & \multicolumn{3}{c}{$\begin{array}{c}\text { Pretreatment sucrose solution } \\
\text { concentration }(\% \mathrm{w}=\mathrm{v})\end{array}$} \\
\cline { 2 - 4 } Pretreatment & 0 & 25 & 50 \\
\hline 0 & $-3.0 \pm 0.2 \mathrm{a}$ & $1.5 \pm 0.1 \mathrm{~b}$ & $3.6 \pm 0.2 \mathrm{c}$ \\
25 & $-3.7 \pm 0.2 \mathrm{a}$ & $2.9 \pm 0.3 \mathrm{c}$ & $5.8 \pm 0.2 \mathrm{~d}$ \\
40 & $-3.9 \pm 0.2 \mathrm{a}$ & $1.3 \pm 0.1 \mathrm{~b}$ & $3.6 \pm 0.3 \mathrm{c}$ \\
\hline
\end{tabular}

Means followed by the same letter are not significantly different by Tukey's test $(p<0.05)$.

Table 3. Water loss (\%) means \pm standard deviation for twoway (Sol*Time) interaction during ultrasound-assisted osmotic dehydration pretreatment of strawberry

\begin{tabular}{cccc}
\hline & \multicolumn{3}{c}{$\begin{array}{c}\text { Pretreatment sucrose solution } \\
\text { concentration }(\% \mathrm{w} / \mathrm{v})\end{array}$} \\
\cline { 2 - 4 } $\begin{array}{c}\text { Pretreatment } \\
\text { time (min) }\end{array}$ & 0 & 25 & 50 \\
\hline 10 & $-2.7 \pm 0.3 \mathrm{~b}$ & $2.1 \pm 0.2 \mathrm{c}$ & $3.5 \pm 0.1 \mathrm{~d}$ \\
20 & $-3.3 \pm 0.0 \mathrm{~b}$ & $1.9 \pm 0.4 \mathrm{c}$ & $4.3 \pm 0.1 \mathrm{e}$ \\
30 & $-3.1 \pm 0.2 \mathrm{~b}$ & $1.6 \pm 0.1 \mathrm{c}$ & $4.6 \pm 0.2 \mathrm{e}$ \\
45 & $-5.0 \pm 0.2 \mathrm{a}$ & $1.9 \pm 0.3 \mathrm{c}$ & $4.8 \pm 0.1 \mathrm{e}$ \\
\hline
\end{tabular}

Means followed by the same letter are not significantly different by Tukey's test $(p<0.05)$.

Table 4. Water loss (\%) means \pm standard deviation for twoway (Freq*Time) interaction during ultrasound-assisted osmotic dehydration pretreatment of strawberry

\begin{tabular}{cccc}
\hline \multirow{2}{*}{$\begin{array}{l}\text { Pretreatment } \\
\text { time (min) }\end{array}$} & \multicolumn{3}{c}{ Pretreatment frequency $(\mathrm{kHz})$} \\
\cline { 2 - 4 } & 0 & 25 & 40 \\
\hline 10 & $0.2 \pm 0.3 \mathrm{a}$ & $2.1 \pm 0.2 \mathrm{~cd}$ & $0.7 \pm 0.2 \mathrm{~b}$ \\
20 & $0.4 \pm 0.1 \mathrm{~b}$ & $2.4 \pm 0.1 \mathrm{~d}$ & $0.1 \pm 0.1 \mathrm{a}$ \\
30 & $1.6 \pm 0.1 \mathrm{c}$ & $1.5 \pm 0.2 \mathrm{c}$ & $0.1 \pm 0.1 \mathrm{a}$ \\
45 & $0.4 \pm 0.1 \mathrm{ab}$ & $0.6 \pm 0.1 \mathrm{~b}$ & $0.7 \pm 0.1 \mathrm{~b}$ \\
\hline
\end{tabular}

Means followed by the same letter are not significantly different by Tukey's test $(p<0.05)$.

For the strawberry halves treated in the $50 \%$ sucrose solution, greater positive water loss was found as water diffused out of the strawberry tissue to lower the osmotic potential of the $50 \%$ osmotic solution. Yet, interestingly, water loss values for strawberry halves pretreated in the $25 \%$ sucrose solution for any length of time were not significantly different from each other. This may be explained by a lower osmotic pressure gradient between the strawberry tissue and the $25 \%$ osmotic solution $(-2560 \mathrm{kPa})$, thus resulting in a more steady net flow of water from the strawberry to the osmotic solution. Nevertheless, the greatest wa- 
ter loss value $(4.8 \%)$ was observed for the strawberry halves pretreated in the $50 \%$ sucrose solution concentration at $45 \mathrm{~min}$ for pretreatment, which is in accordance with the higher osmotic pressure gradient ($5760 \mathrm{kPa}$ ).

For the Freq*Time interaction, significantly greater amounts of water were lost from a pretreatment occurring for strawberry halves at $25 \mathrm{kHz}$ between 10 and $20 \mathrm{~min}$. Increasing the pretreatment time at $25 \mathrm{kHz}$ appeared to actually decrease water loss values. However, increasing the pretreatment time changed the tissue structure of the strawberry, resulting in loss to the solution.

A significant three-way interaction of Sol${ }^{*}$ Time*Freq was observed $(p<0.05)$ during the statistical analysis of the soluble solids gain data. Table 5 presents the mean values for the interaction.

\section{Solids Gain}

Solid gain values tended to increase as the pretreatment solution increased in concentration among the three frequencies. Solid gain values ranged from $-9.1 \%$ at $25 \mathrm{kHz}$ to $-4.0 \%$ at $40 \mathrm{kHz}$ in distilled water compared with $18.7 \%$ at $0 \mathrm{kHz}$ to $41.6 \%$ at $25 \mathrm{kHz}$ in $50 \%$ sucrose solution. Specifically, for the strawberry halves in distilled water, greater negative soluble solids gain (i.e., loss of soluble solids from strawberry tissue) was observed over time. This observation was not unexpected because soluble compounds from within the strawberry halves diffused out of the tissue into the surrounding water with limited dissolved solids. For the straw- berry halves in $50 \%$ sucrose solution at all frequencies, generally greater positive sugar gain was found as sucrose diffused into the strawberry tissue to lower the osmotic potential of the $50 \%$ osmotic solution. Strawberry pretreated at $25 \mathrm{kHz}$ in 25 and $50 \%$ sucrose solutions reached relatively high sugar gain values within 10 to $20 \mathrm{~min}$, which was shorter than the time needed at 0 or $40 \mathrm{kHz}$ to reach similar levels. Increasing pretreatment time at $25 \mathrm{kHz}$ decreased the sugar gain.

However, increasing time of pretreatment broke down part of the tissue structure of the strawberries, which resulted in reduced air-drying time. Studies by Rodrigues and Fernandes ${ }^{[11,25]}$ reported a similar sugar gain behavior in experiments with melon and papaya. This could be similarly related to the absorption effect reported by Cárcel et al. ${ }^{[24]}$ in ultrasound-assisted osmotic dehydration experiments with apples. Apples pretreated for $45 \mathrm{~min}$ at lower frequency levels $(20 \mathrm{kHz})$ yielded higher soluble solids transfer rates compared to runs performed with $44 \mathrm{kHz}$ frequency. Conversely, Cárcel et al. ${ }^{[24]}$ stated that ultrasonic waves at higher frequency intensities seem to be partially absorbed in the liquid medium, thus affecting the degree of penetration into the sample material.

\section{Air Drying}

Moisture content drop during the air-drying procedure for strawberries without pretreatment, pretreated for $30 \mathrm{~min}$ at $25 \mathrm{kHz}$ immersed in a 50\% sucrose solution, and pretreated for $20 \mathrm{~min}$ at $40 \mathrm{kHz}$ immersed in a $50 \%$ sucrose solution are presented in Figure 5. The curves in Figure 5 are representative examples of all

Table 5. Solubles gain (\%) means \pm standard deviation for three-way (Sol*Time*Freq) interaction during ultra-sound assisted osmotic dehydration pretreatment of strawberry

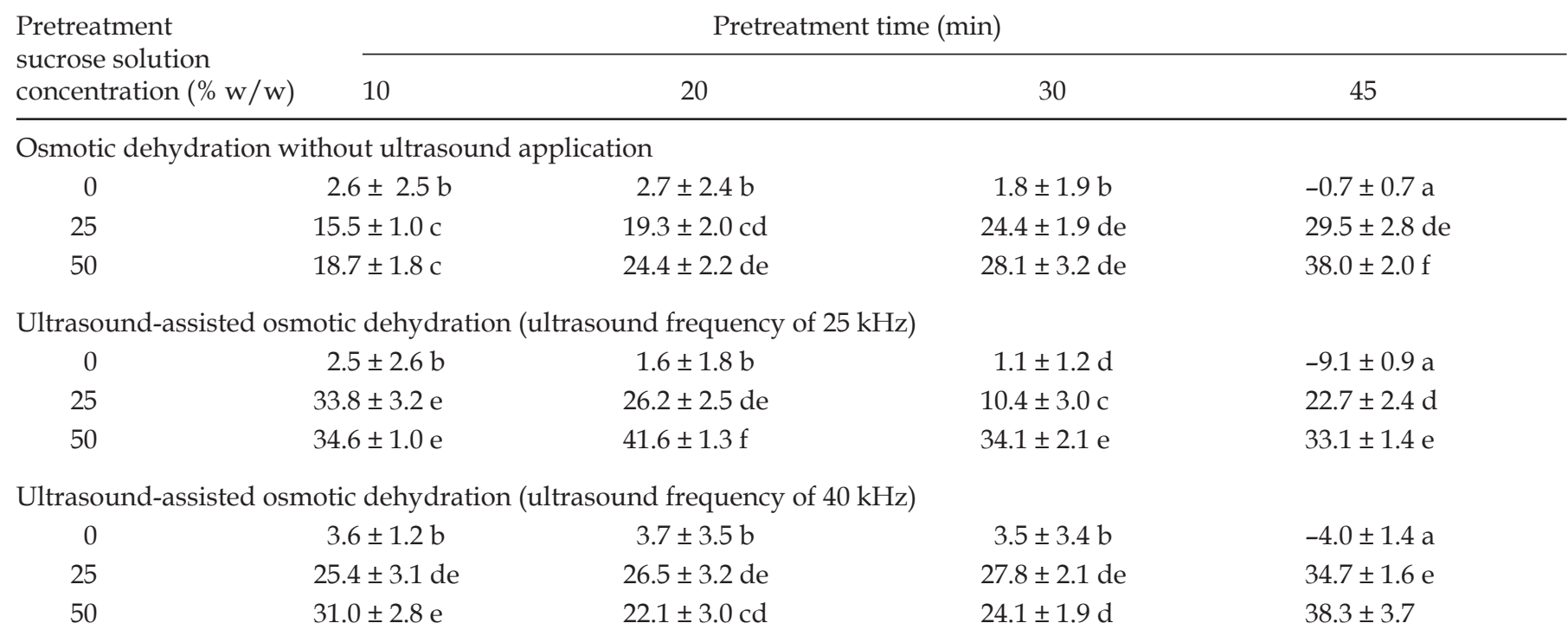

Means followed by the same letter are not significantly different by Tukey's test $(p<0.05)$. 


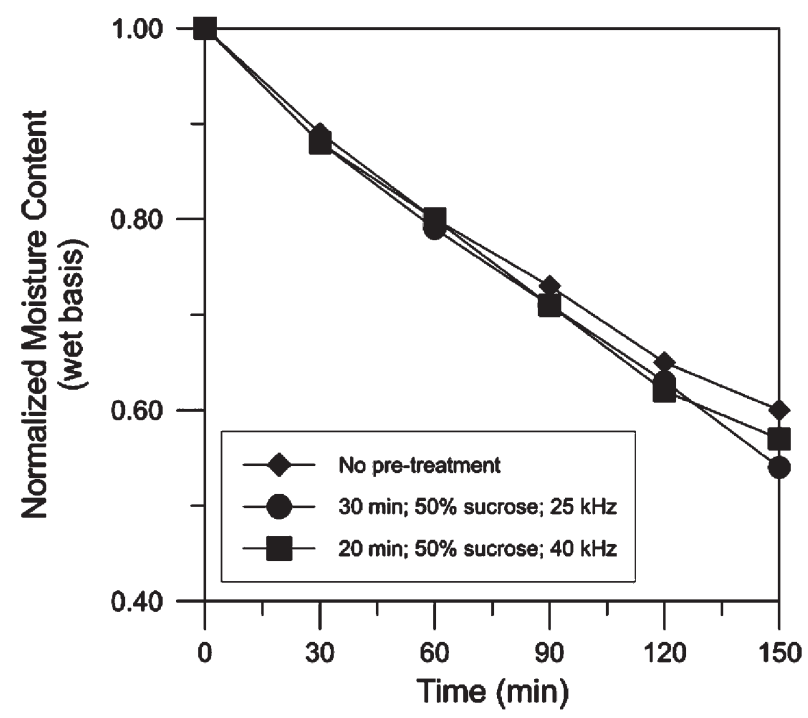

Figure 5. Normalized moisture content (MC) loss in strawberries during air drying as a function of air-drying time for strawberries pretreated for $30 \mathrm{~min}$ at $25 \mathrm{kHz}$ immersed in a $50 \%$ sucrose solution and pretreated for $20 \mathrm{~min}$ at $40 \mathrm{kHz}$ immersed in a 50\% sucrose solution.

drying curves for strawberries subjected to ultrasoundassisted osmotic dehydration. The drying curves presented in Figure 5 presented the greatest deviations from the fresh fruit drying curve.

In the initial stages of drying $(t<90 \mathrm{~min})$, the drying curves for all ultrasound-assisted osmotic dehydration treatments did not deviate much from each other. However, after this time, the fresh fruit sample began to show a steady decrease in drying rate, whereas the pretreated samples maintained greater drying rates than the fresh fruit. More specifically, at $150 \mathrm{~min}$ of drying, considerable differences in moisture content could be observed between fresh fruit and pretreated strawberries.

Figure 6 allows a closer examination of ultrasound effects on normalized moisture content decrease over time during air drying of strawberries. In Figure 6, drying curves for two pretreatments $(30 \mathrm{~min}, 50 \%$ osmotic solution, $25 \mathrm{kHz}$ and $30 \mathrm{~min}, 50 \%$ osmotic solution, $0 \mathrm{kHz}$ ) varying only in frequency level are shown. The pretreatment carried out for 30 min immersed in an osmotic solution of $50 \% \mathrm{w} / \mathrm{w}$ was selected because it resulted in the highest drying rates among the pretreatments.

Effective water diffusivities in strawberries were calculated using the moisture content values recorded over the drying time following pretreatment. Table 6 presents effective water diffusivities values calculated for air drying of strawberries at different experimental conditions.

The highest and lowest effective water diffusivity $2.22 \times 10^{-7}$ and $1.51 \times 10^{-7} \mathrm{~m}^{2} / \mathrm{min}$ respectively, were obtained for the pretreatment carried out for $30 \mathrm{~min}$ $50 \% \mathrm{w} / \mathrm{w}$ osmotic solution and $25 \mathrm{kHz}$ and for the pretreatment carried out for $45 \mathrm{~min} 50 \% \mathrm{w} / \mathrm{w}$ osmotic solution and $40 \mathrm{kHz}$ experimental unit. The effective water diffusivity of the fresh fruit was $1.50 \times 10^{-7} \mathrm{~m}^{2} / \mathrm{min}$.

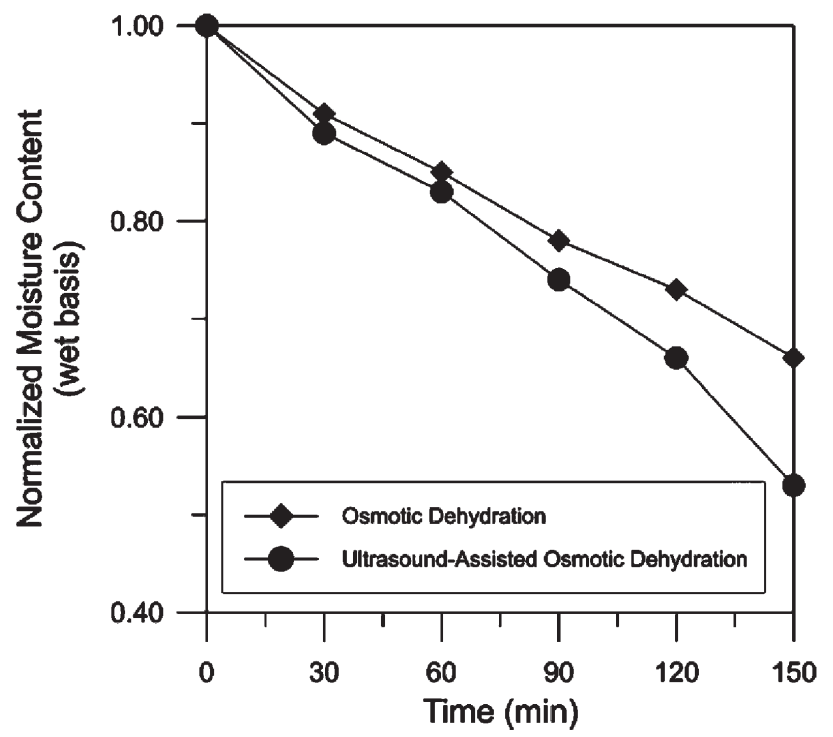

Figure 6. Normalized moisture content (MC) loss in strawberries during oven drying as a function of processing time for pretreatments carried out for $30 \mathrm{~min}$ immersed in a $50 \%$ osmotic solution.

Comparing the effective water diffusivity for the process during which the pretreatment was carried out for $30 \mathrm{~min} 50 \% \mathrm{w} / \mathrm{w}$ osmotic solution and $25 \mathrm{kHz}$ showed an increase of $44 \%$ in the effective water diffusivity.

Increased effective water diffusivity has been associated with formation of microscopic channels in the intercellular tissue of fruits by Fernandes et al. ${ }^{[18,19]}$ and Cárcel et al. ${ }^{[24]}$ As evidenced in the photomicrographs, the formation of microscopic channels by means of ultrasound-assisted osmotic dehydration may occur in one of two ways: elongation and separation of cells due to cavitation (ultrasound-assisted pretreatment in distilled water) or disruption and breakdown of cells due to the combined effects of cavitation and osmotic pressure (ultrasound-assisted osmotic dehydration).

Effective water diffusivity for strawberry samples observed during the drying process was found to be higher when ultrasound-assisted osmotic dehydration pretreatment was implemented. However, neither higher osmotic concentrations nor ultrasonic application for extended periods always resulted in higher effective water diffusivity in pretreated strawberries. Fernandes et al. ${ }^{[26]}$ demonstrated in experiments with pineapples that ultrasound-assisted osmotic dehydration at high osmotic concentrations ( $\left.>35^{\circ} \mathrm{Brix}\right)$ and long periods of treatment (>20 $\mathrm{min}$ ) may actually result in a drop of effective water diffusivity values compared to less severe ultrasound-assisted osmotic dehydration pretreatments at lower osmotic concentrations and frequency.

Fernandes et al. ${ }^{[26]}$ also attributed such a decrease in effective water diffusivity to greater transfer of solubles into the cellular tissue of the fruit from the osmotic solution, thus creating extra resistance or less potential for water to diffuse out of the berry tissue. In this study, 
pretreatments carried out at $40 \mathrm{kHz}$ resulted, in general, in lower effective water diffusivity values than the effective water diffusivity values for fresh strawberry. This result is consistent with the observations published by Cárcel et al. ${ }^{[24]}$ stating that at higher frequencies $(>25$ $\mathrm{kHz}$ ) the ultrasonic energy is absorbed by the liquid medium and, in consequence, ultrasonic waves do not penetrate as deeply into the solid matrix of the fruit.

Ultrasonic waves were expected to promote cavitation and induce the formation of microchannels within the tissue of fruit. Fernandes et al. ${ }^{[26]}$ reported that the number of microchannels produced may actually increase with time, yet such an increase is not unlimited. In this study, microchannel formation was showed to vary according to the frequency level. Nevertheless, high ultrasonic frequencies along with high osmotic concentrations may actually disrupt the fruit tissue in such a manner that water diffusion is compromised during the drying process.

\section{Optimal Conditions}

Previous studies suggested that for an osmotic dehydration process followed by hot air drying, optimal processing time results when osmotic dehydration is used to increase the drying rate of fruit. ${ }^{[6,11,25,26]}$ Table 7 shows the total processing (pretreatment + air drying) times to achieve $90 \%$ moisture content removal in strawberry halves.

Ultrasound-assisted osmotic dehydration of strawberry halves at $25 \mathrm{kHz}$ for $30 \mathrm{~min}$ in a $50 \%$ sucrose solution needed the shortest total processing time of $455 \mathrm{~min}$ to achieve $90 \%$ reduction in moisture content. Under the same osmotic conditions (50\% and $30 \mathrm{~min}$ ) without the application of ultrasonic waves, the total processing time was $903 \mathrm{~min}$. When compared to fresh, untreated berries (612 min of processing time), these times resulted in a 157 -min reduction $(25.7 \%)$ and a $291-\mathrm{min}$ increase $(47.6 \%)$ in total processing time, respectively.

Osmotic dehydration alone during pretreatment increased the total processing time, whereas ultrasoundassisted osmotic dehydration during pretreatment generally reduced the total processing time. The increase in processing times using osmotic solutions (without ultrasound application) may be due to the formation of a sucrose layer on the surface of the strawberries.

Overall, strawberries submitted to ultrasound-assisted osmotic dehydration were observed to dry in less time during the air-drying stage than fresh, untreated fruit. Formation of microchannels in strawberry samples pretreated by ultrasound-assisted osmotic dehydration, occurring due to changes in intercellular tissue (i.e., primary and secondary cell walls), may have accounted for the time difference. The tissue changes were likely induced by cavitation and as a consequence of the combined effects of osmotic pressure and fatigue induced by ultrasonic waves.
Table 6. Effective water diffusivity values from air drying strawberry halves pretreated at different experimental ultrasonic-assisted osmotic dehydration conditions

\begin{tabular}{ccc}
$\begin{array}{l}\text { Sucrose solution } \\
\text { concentration } \\
(\% \mathrm{w} / \mathrm{w})\end{array}$ & $\begin{array}{c}\text { Time } \\
(\mathrm{min})\end{array}$ & $\begin{array}{c}\text { Effective water } \\
\text { diffusivity }\left(\mathrm{m}^{2} / \mathrm{min}\right)\end{array}$ \\
\hline $\begin{array}{c}\text { Osmotic dehydration } \\
0\end{array}$ & 10 & $1.52 \times 10^{-7} \pm 0.10 \times 10^{-7}$ \\
0 & 20 & $1.54 \times 10^{-7} \pm 0.18 \times 10^{-7}$ \\
0 & 30 & $1.54 \times 10^{-7} \pm 0.13 \times 10^{-7}$ \\
0 & 45 & $1.53 \times 10^{-7} \pm 0.09 \times 10^{-7}$ \\
25 & 10 & $1.56 \times 10^{-7} \pm 0.08 \times 10^{-7}$ \\
25 & 20 & $1.53 \times 10^{-7} \pm 0.07 \times 10^{-7}$ \\
25 & 30 & $1.68 \times 10^{-7} \pm 0.09 \times 10^{-7}$ \\
25 & 45 & $1.63 \times 10^{-7} \pm 0.14 \times 10^{-7}$ \\
50 & 10 & $1.67 \times 10^{-7} \pm 0.11 \times 10^{-7}$ \\
50 & 20 & $1.69 \times 10^{-7} \pm 0.14 \times 10^{-7}$ \\
50 & 30 & $1.66 \times 10^{-7} \pm 0.10 \times 10^{-7}$ \\
50 & 45 & $1.59 \times 10^{-7} \pm 0.09 \times 10^{-7}$
\end{tabular}

Ultrasound-assisted osmotic dehydration (ultrasound frequency of $25 \mathrm{kHz}$ )

$\begin{array}{rll}0 & 10 & 1.61 \times 10^{-7} \pm 0.10 \times 10^{-7} \\ 0 & 20 & 1.75 \times 10^{-7} \pm 0.04 \times 10^{-7} \\ 0 & 30 & 1.87 \times 10^{-7} \pm 0.13 \times 10^{-7} \\ 0 & 45 & 1.97 \times 10^{-7} \pm 0.12 \times 10^{-7} \\ 25 & 10 & 1.98 \times 10^{-7} \pm 0.12 \times 10^{-7} \\ 25 & 20 & 1.64 \times 10^{-7} \pm 0.11 \times 10^{-7} \\ 25 & 30 & 1.72 \times 10^{-7} \pm 0.13 \times 10^{-7} \\ 25 & 45 & 1.61 \times 10^{-7} \pm 0.07 \times 10^{-7} \\ 50 & 10 & 1.59 \times 10^{-7} \pm 0.07 \times 10^{-7} \\ 50 & 20 & 1.72 \times 10^{-7} \pm 0.10 \times 10^{-7} \\ 50 & 30 & 2.22 \times 10^{-7} \pm 0.13 \times 10^{-7} \\ 50 & 45 & 1.73 \times 10^{-7} \pm 0.09 \times 10^{-7}\end{array}$

Ultrasound-assisted osmotic dehydration (ultrasound frequency of $40 \mathrm{kHz}$ )

$\begin{array}{lll}0 & 10 & 1.57 \times 10^{-7} \pm 0.12 \times 10^{-7} \\ 0 & 20 & 1.64 \times 10^{-7} \pm 0.10 \times 10^{-7} \\ 0 & 30 & 1.64 \times 10^{-7} \pm 0.11 \times 10^{-7} \\ 0 & 45 & 1.70 \times 10^{-7} \pm 0.05 \times 10^{-7} \\ 25 & 10 & 1.84 \times 10^{-7} \pm 0.08 \times 10^{-7} \\ 25 & 20 & 1.78 \times 10^{-7} \pm 0.08 \times 10^{-7} \\ 25 & 30 & 1.58 \times 10^{-7} \pm 0.06 \times 10^{-7} \\ 25 & 45 & 1.53 \times 10^{-7} \pm 0.04 \times 10^{-7} \\ 50 & 10 & 1.85 \times 10^{-7} \pm 0.11 \times 10^{-7} \\ 50 & 20 & 1.99 \times 10^{-7} \pm 0.12 \times 10^{-7} \\ 50 & 30 & 1.69 \times 10^{-7} \pm 0.06 \times 10^{-7} \\ 50 & 45 & 1.51 \times 10^{-7} \pm 0.09 \times 10^{-7}\end{array}$


Table 7. Total processing time (pretreatment + oven drying) to achieve $90 \%$ moisture content reduction at different conditions

\begin{tabular}{|c|c|c|c|c|}
\hline Pretreatment & $\begin{array}{r}\text { Ultrasound } \\
\text { frequency }(\mathrm{kHz})\end{array}$ & $\begin{array}{r}\text { Pretreatment } \\
\text { time (min) }\end{array}$ & $\begin{array}{l}\text { Air-drying } \\
\text { time (min) }\end{array}$ & $\begin{array}{r}\text { Total processing } \\
\text { time (min) }\end{array}$ \\
\hline No pretreatment & - & - & 612 & 612 \\
\hline Osmotic dehydration (25\% solution) & - & 10 & 673 & 683 \\
\hline Osmotic dehydration (25\% solution) & - & 30 & 760 & 790 \\
\hline Osmotic dehydration (50\% solution) & - & 20 & 891 & 911 \\
\hline Ultrasound osmotic dehydration ( $25 \%$ sol.) & 25 & 10 & 479 & 489 \\
\hline Ultrasound osmotic dehydration ( $25 \%$ sol.) & 40 & 30 & 589 & 619 \\
\hline Ultrasound osmotic dehydration (50\% sol.) & 25 & 30 & 425 & 455 \\
\hline Ultrasound osmotic dehydration ( $50 \%$ sol.) & 40 & 20 & 474 & 494 \\
\hline
\end{tabular}

\section{CONCLUSION}

Considerable differences in moisture content loss can be observed between fresh strawberry halves and ultrasound-assisted osmotic dehydration pretreated strawberries during air drying. The pretreatment carried out for $30 \mathrm{~min}$ immersed in a $50 \% \mathrm{w} / \mathrm{w}$ osmotic solution resulted in the highest drying rates among the pretreatments. Cell distortion and breakdown were observed in pretreatments employing not only ultrasound but also osmotic solutions.

Effective water diffusivity for strawberries was found to be generally higher when ultrasound-assisted osmotic dehydration pretreatment was implemented prior to drying. Osmotic dehydration alone during pretreatment increased total processing time, whereas osmotic dehydration combined with ultrasonic energy during pretreatment reduced total processing time.

Greater sucrose concentration used in ultrasoundassisted osmotic dehydration resulted in greater water loss and the greatest water loss value $(4.8 \%)$ was observed for the strawberry halves pretreated in the 50\% sucrose solution concentration at $45 \mathrm{~min}$ of pretreatment. Greater amounts of water were lost from a pretreatment occurring for strawberry halves at $25 \mathrm{kHz}$ between 10 and 20 min than for other times. Strawberry halves pretreated at $25 \mathrm{kHz}$ in 25 and $50 \% \mathrm{w} / \mathrm{w}$ sucrose solutions reached relatively high soluble solid gain within 10 to $20 \mathrm{~min}$, which was shorter than the time needed at 0 or $40 \mathrm{kHz}$ to reach similar levels. The main factor for such reduction was attributed to the formation of microchannels caused by ultrasonic application and the effects of osmotic pressure gradient. Higher sucrose concentrations at longer pretreatment periods of ultrasound-assisted osmotic dehydration may have caused the obstruction of microchannels with soluble solids, reducing sugar mass transfer from the osmotic solution into the matrix of the fruit and also water diffusion during air drying.

\section{ACKNOWLEDGMENTS}

The authors are grateful for the financial support provided through the Hatch Act, USDA; by the College of Engineering at the University of Nebraska-Lincoln; and the Brazilian funding institutes, CNPq and CAPES. The authors recognize the support offered by Dr. David Marx from the Department of Statistics at the University of Nebraska-Lincoln.

\section{REFERENCES}

1. Doymaz, I. Convective drying kinetics of strawberry. Chemical Engineering Processing 2007, 47, 914-919.

2. Fernandes, F.A.N.; Rodrigues, S. Application of ultrasound and ultrasound-assisted osmotic dehydration in drying of fruits. Drying Technology 2008, 26, 1509-1516.

3. Raghavan, G.S.V.; Silveira, A.M. Shrinkage characteristics of strawberries osmotically dehydrated in combination with microwave drying. Drying Technology 2001, 19, 405-414.

4. Venkatachalapathy, K.; Raghavan, G.S.V. Combined osmotic and microwave drying of strawberries. Drying Technology 1999, 17, 837-853.

5. Torreggiani, D. Osmotic dehydration in fruit and vegetable processing. Food Research International 1993, 26, 59-68.

6. Fernandes, F.A.N.; Rodrigues, S. Use of ultrasound as pretreatment for drying of fruits: Dehydration of banana. Journal of Food Engineering 2007, 82, 261-267.

7. Fernandes, F.A.N.; Rodrigues, S. Dehydration of sapota (Achras sapota L.) using ultrasound as pretreatment. Drying Technology 2008, 26, 1232-1237.

8. Stojanovic, J.; Silva, J.L. Influence of osmoconcentration, continuous high-frequency ultrasound and dehydration on properties and microstructure of rabbiteye blueberries. Drying Technology 2006, 24, 165-171.

9. Giraldo, G.; Talens, P.; Fito, P.; Chiralt, A. Influence of sucrose solution concentration on kinetics and yield during osmotic dehydration of mango. Journal of Food Engineering 2003, 58, 33-43.

10. Fuente-Blanco, S.; Sarabia, E.R.F.; Acosta-Aparicio, V.M.; Blanco-Blanco, A.; Gallego-Juárez, J.A. Food drying pro- 
cess by power ultrasound. Ultrasonics Sonochemistry 2006, 44, e523-e527.

11. Rodrigues, S.; Fernandes, F.A.N. Ultrasound in fruit processing. In New Food Engineering Research Trends; Urwaye, A.P., ed.; Nova Science Publishers: Hauppauge, NY, 2007; 103-135.

12. Xu, H.S.; Zhang, M.; Duan, X.; Mujumdar, A.; Sun, J. Effect of power ultrasound pretreatment on edamame prior to freeze drying. Drying Technology 2009, 27, 186-193.

13. García-Pérez, J.V.; Cárcel, J.A.; Riera, E.; Mulet, A. Influence of the applied acoustic energy on the drying of carrots and lemon peel. Drying Technology 2009, 27, 281-287.

14. AOAC. Official Methods of Analysis; Association of Official Analytical Chemists: Washington, DC, 1990.

15. Teles, U.M.; Fernandes, F.A.N.; Rodrigues, S.; Lima, A.S.; Maia, G.A.; Figueiredo, R.W. Optimization of osmotic dehydration of pineapples followed by air-drying. International Journal of Food Science and Technology 2006, 41, 674-680.

16. Perry, R.H.; Green, D.W. Perry's Chemical Engineer's Handbook; McGraw Hill: New York, 1999.

17. Maia, V. Técnica Histológica; Atheneu: São Paulo, Brazil, 1979.

18. Fernandes, F.A.N.; Gallão, M.I.; Rodrigues, S. Effect of osmotic dehydration and ultrasound pre-treatment on cell structure: Melon dehydration. LWT - Food Science and Technology 2008, 41, 604-610.

19. Fernandes, F.A.N.; Gallão, M.I.; Rodrigues, S. Effect of osmosis and ultrasound on pineapple cell tissue structure during dehydration. Journal of Food Engineering 2009, 90, 186-190.

20. Rodrigues, S.; Oliveira, F.I.P.; Gallão, M.I.; Fernandes, F.A.N. Effect of immersion time in osmosis and ultrasound on papaya cell structure during dehydration. Drying Technology 2009, 27, 220-225.

21. Prinzivalli, C.; Brambilla, A.; Maffi, D.; Scalzo, R.L.; Torreggiani, D. Effect of osmosis time on structure, texture and pectic composition of strawberry tissue. European Food Research and Technology 2006, 224, 119-127.

22. Fernandes, F.A.N.; Rodrigues, S.; Gaspareto, O.; Oliveira, E.L. Optimization of osmotic dehydration of papaya followed by air-drying. Food Research International 2006, 39, 492-498.

23. Fernandes, F.A.N.; Rodrigues, S.; Gaspareto, O.; Oliveira, E.L. Optimization of osmotic dehydration of bananas followed by air-drying. Journal of Food Engineering 2006, 77, 188-193.

24. Cárcel, J.A.; Benedito, J.; Rosselló, C.; Mulet, A. Influence of ultrasound intensity on mass transfer in apple immersed in a sucrose solution. Journal of Food Engineering 2007, 78, 472-479.

25. Rodrigues, S.; Fernandes, F.A.N. Use of ultrasound as pretreatment for dehydration of melons. Drying Technology 2007, 25, 1791-1796.

26. Fernandes, F.A.N.; Linhares, F.E., Jr.; Rodrigues, S. Ultrasound as pre-treatment for drying of pineapples. Ultrasonics Sonochemistry 2008, 15, 1049-1054. 